\title{
Challenges in a Changing World *
}

\author{
by \\ Professor Sir Harold P. Mitchell, Bt, MA(Oxon), D. ès Sc.Pol.(Geneva), Hon.LLD. \\ Chairman \& Chief Executive of Luscar Group, 800 Royal Trust Tower, Edmonton Centre, Edmonton, Alberta, Canada; \\ Marshall's Island, P.O. Box 901, Hamilton, Bermuda; Maison Silence, 3920 Zermatt, Switzerland.
}

\section{INTRODUCTION}

In this paper I would like to examine some of the challenges which we, the human race, must now inevitably face. I propose to do so from the point of view of one experienced in mining and farming, politics, business, and the academic world; in short, from the point of view of a generalist. I have had an opportunity to travel widely, to see problems at first hand, and to meet and talk with people in many countries; and I have business interests in both the developed and the developing worlds. I have spent my life watching humanity from many different angles.

Only in the last twenty years or so has our attention been drawn to some of the challenges which now inexorably confront us-as indicated, for example, in Polunin (1972, 1974-). They are global: every country and all people are involved in them, and are affected by them. Nations are increasingly interdependent-if in no other way than in competition for food and the world's decreasing resources. But not surprisingly, the challenges of the developed world-of North America, Europe, the Soviet Union, Japan, Australia, and New Zealand-are different from those of the developing world. I shall limit my discussion, as far as the developed world is concerned, to three major challenges: pollution and the environment, energy, and our relations with the developing world. I shall then consider three challenges faced by the developing world: population, food supplies, and education.

\section{THE DEVELOPED WORLD}

\section{Population Growth}

I am making two assumptions concerning the developed world. The first is that its population will continue to be fairly stable and will grow very slowly. At the moment, there are 1.1 thousand million people

* Substance of the Henry Marshall Tory Lecture delivered in Edmonton, Alberta, Canada, on 17 October 1977. in it, or rather less than $30 \%$ of the world's total population. According to figures prepared recently by the Population Reference Bureau (1977a), the annual rate of population growth in Canada is $0.8 \%$, in the United States it is $0.6 \%$, in the Soviet Union $0.9 \%$, and in Europe on average $0.4 \%$. It will take between 80 and 200 years for the populations of these areas to double, if their current rates of increase continue. Growth is very slow in the developed countries, and they will have time to cope with the new numbers, to build houses, schools, hospitals, and, hopefully, to find work for their people.

There are two points to note about this growth. First, population density will increase, with most people continuing to live in cities. Secondly, the age-distribution of these populations will change. In 1975 the median age of the U.S.A.'s population was 28 ; by the year 2000 it will probably be about 35 . In 1975, those over 64 accounted for $10 \%$ of the population of the United States; this will rise to $11.6 \%$ in the year 2000 (Bouvier, 1975). By that time, the "baby boom' children of the 1940 s will be nearing retirement age. Will relatively smaller work-forces be able to support them and pay for their pensions? Even though we in the developed world have time to make adjustments, we still face problems in ordering our societies to meet the needs of our changing population.

\section{Food Supplies}

My other assumption is that the developed world will not only be able to feed itself, but also much of the rest of the world if necessary. Canada, the United States, Australia, and Argentina, are the major wheat exporters of the world. During the last decade they have faced a boom-bust situation. In the late 1960s, production and food stocks were cut back sharply because grain prices were falling; increasing amounts of wheat were used for livestock feed. The fall of grain stocks, together with the bad harvests in the Soviet Union, which made her a major purchaser, triggered

Environmental Conservation, Vol. 5, No. 1, Spring 1978-C) 1978 The Foundation for Environmental Conservation-Printed in Switzerland. 
off a grain crisis. The World Food Conference in Rome in 1974 responded by calling for the creation of an international grain reserve to be used to avert outright famine.

Now again the world's granaries are bursting. The Carter Administration, in addition to moving to create a national farmer-owned grain reserve, has proposed that American farmers take a fifth of their normal wheat acreage and a tenth of their feed-grain acreage out of production (Anon., 1977a). If these proposals are accepted, in three or four years' time, perhaps after bad harvests, will they go into production again? We must find a way to stabilize the amount of food we grow, and discover a method, satisfactory to all, to get food to those who need it (Tinbergen, 1977).

Farming in the developed world is generally an efficient, but a very energy-intensive, industry. In Britain, agriculture employs only $3 \%$ of the working population; energy has replaced labour. In Only One Earth, Barbara Ward \& René Dubos (1972) asked an important question about modern agriculture:

'May not the whole development of modern industralized farming, with heavy machinery and a very heavy use of fertilizers, represent a dangerous simplification, a trend towards a monoculture which, being of its very nature far more fragile and vulnerable than balanced, complex ecosystems, exposes mankind to the risk of securing high food [yields] in the shorter run in return for catastrophic risks of famine later on?'

It looks as though we shall be able to feed ourselves, but at what price? You are all probably familiar with the story of DDT. When it was first introduced thirty years ago, it appeared to be capable of wiping out the multitude of pests which affect mankind. Few people suspected that it had the same capacity as mercury to become more concentrated as it moved up the foodchain. Dr Paul Ehrlich (1971), in The Population $B o m b$, suggested that 'The day may come when the obese people of the world must give up diets, since metabolizing their fat deposits will lead to DDT poisoning'. And is this such an exaggeration? Will we have to continue to use pesticides such as DDT, which enter the food-chain-with consequences of which we are not yet fully aware?

\section{POLLUTION AND THE ENVIRONMENT}

This leads me to the first challenge which we, the developed world, must face: what we are doing to our environment by polluting the air, water, and land. I suspect that you are all aware of at least one pollution problem, either from first-hand experience-having seen the pollution of a lake or stream or experienced smog in a city-or through the efforts to arouse awareness that were pioneered by the late Rachel Carson. Pollution will continue to be a part of Man's increasingly technological activity, and there will always be wastes to dispose of in the environment. Disposal is a legitimate procedure, provided we do not overtax the environment's capacity to deal with our wastes. The extent to which society allows the environment to be used in this way depends primarily upon the value which Man places on the environment (Moore, 1975).

Steps to alleviate Man's impact have been and are being taken by individuals and by governments, but progress is slow. Within my own sphere, the coal company with which $I$ have long been associated in Canada has been concerned to repair the destruction to the environment which its operations have caused. In one area of the Rockies we are re-seeding the grassy tracts from underneath which the coal has been extracted. We are far above the level of farm-land-between 5,000 and 6,000 feet (1,524 and 1,829 metres) - but it is fascinating to see mountain sheep (Ovis sp.), and also deer, feeding on our newly-sown grass in preference to the areas untouched by us. The U.S. Congress is considering a bill which would require strip-miners of coal to restore the land to its original condition.

Britain's Clean Air Act is one example of how legislation can make a difference. The Act prohibits emissions of smoke from chimneys in particular areas, and has been highly successful in preventing London's famous pea-soup fogs. Of course the cost of pollution control and land reclamation is passed on to the consumer. Britain's smokeless fuel, for example, is more expensive than the untreated variety.

How can we judge the world's success so far in dealing with this problem? In 1976, a team from the British Cabinet Office (cf. 1976) regarded the outlook optimistically:

'In most developed countries pollution has become a diminishing problem as awareness, scientific understanding, and technological capacities, have grown... There is a tendency, however, for the energy cost of pollution abatement or prevention to rise disproportionately as populations grow and the standard of living and technological development increase. [So] the developing countries may find it difficult, as they go through the early stages of industrialization, to meet the pollution standards adopted by developed countries.'

Latterly a Canadian expert, F. K. Hare (1977), has regarded the situation as still gloomy. He argues that public anxiety about the environment has receded in the face of more pressing problems: inflation, rising unemployment, food and energy supply crises, guerilla attacks, and personal and institutional corruption. He believes that the lack of strong majority governments has further limited our ability to act; but he does see progress in the field of environmental education. Increasing numbers of people recognize the need to protect our environment, and realize that we can no longer go on taking for granted the free use of air, 
water, and land. To clean up our environment is essentially a technological problem-we have, or are developing, the means to do it. But does our world have the will?

\section{ENERGY}

The problem of pollution is most closely linked to our second challenge-that of energy and the use thereof. This is a subject of deep interest to someone who has been closely associated through his whole life with the fossil-fuel industries - with coal and latterly with oil. Recognition of the energy crisis is a recent phenomenon. It came home to most of us at the time of the 1973 Middle East war. In the last thirty years, total energy consumption has risen more rapidly than total population. World population since 1950 has increased by $60 \%$; per caput energy consumption has risen between 100 and $600 \%$ in different countries (Population Reference Bureau, 1977b).

\section{Consumption Patterns}

In the past quarter-century the balance between production and consumption has changed. In 1950 the major energy-producing regions were the major energy consumers. The United States produced $44 \%$ of the total and consumed $45 \%$. By 1974, there were major imbalances. Western Europe produced $7 \%$ of total world energy, but consumed $19 \%$. The Middle East produced $36 \%$ of the world's oil supply, but consumed only $2 \%$ (Population Reference Bureau, 1977b). This imbalance has raised significant economic problems for the countries that now find themselves to be energy importers, and has threatened to change the balance in world politics. As Mason Willrich (1976) noted in an article in International Affairs:

'If the US government cannot opt decisively for energy independence and the American people do not make the sacrifices necessary to achieve this goal, then America's current role as one of the two super-powers with certain global security responsibilities may be in serious doubt'.

The developed world, containing less than $30 \%$ of the world's people, uses $80 \%$ of total energy consumed in the world each year. American energy consumption has gone up an average of $3.5 \%$ per year since 1935, and doubles every 20 years. It is inevitable that Northern Hemisphere countries will use more energy per caput than other parts of the world, if only to heat buildings in winter and to drive their industrial machine. However, as more nations become more developed and industrialized, the demand for energy will move in the direction of American energy-consumption trends. Demand will climb steeply unless and until costs become prohibitive. It is projected that in the next 25 years, world energy demand may treble (Population Reference Bureau, 1977b). Where will the energy come from?

\section{Alternative Sources}

If exponential growth of consumption continues, energy supplies will be severely taxed. The lastest predictions indicate that known oil reserves will have run dry by the year 2000 . Known coal reserves, however, could last very much longer (possibly over 2,000 years according to Meadows et al., 1972), which is why President Carter put such emphasis on developing coal resources. Long before these sources of energy - known to economists as 'cheap' energyrun out, they will have ceased to be cheap. It will become prohibitively expensive to use fossil fuels for anything but the most necessary activity. What are the alternatives? One possible solution to this problem is the use of nuclear energy. There are at present 194 nuclear-power reactors operating in twenty countries. If construction goes ahead as planned, by 1985 there will be over 600 in 39 countries (Anon., 1977b). The spread of nuclear power-stations around the world will be a tremendous challenge, for there are very grave dangers inherent in their development (e.g. Edsall, 1974, 1975).

What would happen if a nuclear power-station were destroyed in an earthquake? How are we to store and/ or dispose safely of nuclear wastes, some of which give off their deadly radiation for many thousands of years? Nuclear plants release considerable quantities of heat into the atmosphere. What will their increasing, world-wide use do to the earth's temperature and how will climate be affected? And the spread of nuclear power-plants increases the danger of nuclear theft. Nuclear weapons are relatively easy to make if materials are available. These materials are and will be readily to hand if nuclear power-plants proliferate. Without effective safeguards to prevent theft, the development of nuclear power will create substantial risks to the security and safety of all people (Willrich \& Taylor, 1974).

I think our challenge regarding energy is to find other, better sources, to explore more fully wind and water power, and above all solar and geothermal energy. This will take time and cost money, but we have no choice. Allied to this, we will need to develop energy conservation practices by expanding mass transit systems, producing smaller cars, improving insulation and heating systems, and reclaiming and recycling materials.

\section{Is Growth Necessary?}

Now let us step back a moment and ask an even more serious question. Most forecasters concur that our consumption of energy will increase for the rest of this century and that we need this energy for economic growth. But is the cost of growth too high? Given the most optimistic assumptions about advances in technology and the discovery of new sources of energy 
and raw materials, the Earth cannot support present rates of economic and population growth indefinitely. We in the developed world are like a slightly overweight person whose doctor has warned him that if he goes on at his present rate, he will be bloated beyond belief in 25 years. His instinct is to go to a steam-bath or use mechanical rollers. He could of course cut down a bit. We have so far faced the energy problem by prescribing palliatives; we have not yet really begun to cut down. Americans made an effort recently by reducing the temperature in their homes. The severity of the weather and the shortages of natural gas brought the energy problem home to millions. But this grim warning has not been heeded; President Carter's energy programme is foundering in Congress, and sales of 'gas guzzlers' have risen.

The real pity is that it is not the developing world, whose need for energy is often acute, that is using it. The higher the standard of living, the higher the demand for energy. If there are already pressures on energy sources, what will happen when developing countries attain a higher standard of development and require more of the energy pie?

Think how our lives would be changed without the automobile. How would we get to work? How would we do our shopping and spend our leisure time? We none of us want to return to life-styles as they were before the Industrial Revolution; we have come too far for that. But sooner or later our lifestyles will have to change. Let us hope that the movement to new ones will be by evolution rather than radical, enforced change. The challenge that we face with regard to energy is to develop new sources, while moderating our own consumption.

\section{RELATIONS WITH THE THIRD WORLD}

The final challenge of the developed world which I shall consider is its relations with the developing world. These are basically of two kinds-aid and trade, which, of course, both have political implications. A change has come about in our relations with the developing world in the aftermath of the 1973 oil embargo. A new militancy has entered into our dialogue. The developing world is attacking the privileges of the developed world. It became clear during the Commonwealth Conference in London in June 1977 that there was a wide conceptual difference about the cause of the gap in well-being between rich and poor nations. President Julius Nyerere of Tanzania argued that the developed countries owe the poorer countries a wealth transfer as recompense for past and present exploitation (Fanon, 1963). Do we? The developing world has benefited from its links with the developed world; contact between them has been the mainspring of economic development and higher living standards. Nor are we responsible for the poverty which exists in the developing world. Few, however, would deny that we have a moral responsibility to help the desperately poor.

The dialogue between the two worlds is difficult, but is going on at many levels. Last year we saw a flurry of activity - the London Commonwealth Conference and, also in June, the Conference for International Economic Co-operation (the 'North-South dialogue') which took place in Paris. The latter was not an overwhelming success. The poor countries drew attention to their major problems: the need for debt relief, for more aid, and for access to the markets of the rich in order to enhance their earning- and buying-power. The rich responded by agreeing to establish a common fund to help stabilize some raw material prices and also to the creation of a $\$ 1$ thousand millions fund to provide emergency assistance to the poor countries, but they rejected all attempt to make them commit $0.7 \%$ of their Gross National Products for aid by 1980 . The Carter Administration did, however, promise an extra $\$ 375$ millions in aid (Anon., 1977c; Field, 1977).

\section{Aid and Trade}

Granted that our aid in the past has probably not been enough, has it been of the right kind? Developing countries must concentrate on achieving more efficient agriculture and develop small-scale industry. The British Government has now earmarked more of its aid to 'appropriate technology', which the late E. F. Schumacher (1973) advocated in Small is Beautiful. More of its aid will henceforth go to developing and improving labour-intensive rather than labour-saving technology, in order to create more opportunities and make work more productive. Many leaders in the developing world, however, dislike these suggestions. They fear that they are being cheated-that the developed world wants to do the pleasant work, leaving them to sweat in the fields. And making agriculture more efficient may require land reform-a delicate social question that is not easy to solve.

In addition to providing more aid, and more effective aid, we must make changes in trade patterns. The Times of London (Anon., 1977d) pointed out why this is necessary:

'The intellectual argument for raising living standards in the Third World is that, at a time when the absorptive capacity of the rich markets for more products appears limited, the larger potential markets of the developing countries could provide a new engine for growth, exports, and jobs for the world economy as a whole. The problem is how to convert the great needs of southern [developing] nations into effective monetary demand'.

This problem can be alleviated in several ways: more money can be placed at the disposal of the World Bank, the borrowing capacity of the developing 
nations can be improved, and more aid can be given. Or the developing countries could be allowed to earn more by their own foreign trade, inter alia by a reduction of our tariffs. If the rich do not give way voluntarily, they might face cartels similar to the Organization of Petroleum Exporting Countries, but affecting other commodities such as have been tried, unsuccessfully, with sugar and bauxite. The next round of the General Agreement on Tariffs and Trade negotiations will be crucial as indicating the attitude of the developed world. An editorial in The Times (Anon., 1977e) summed up the challenge we face:

'If developing countries begin to lose faith in their own ability to develop and in the willingness of the rich to help them, they can very quickly bring a lot of trouble on themselves and the world'.

\section{THE DEVELOPING WORLD}

The challenges faced by the developing world, which we all share, are basically economic and social. I shall discuss three major ones: population, food supply, and education.

\section{POPULATION}

The most serious problem, particularly for its longterm consequences, is that of population. It must be the starting point for all discussion, as over $70 \%$ of the world's people live in the developing world, and they increase at the rate of over $2 \%$ per annum. Though this increase may not sound very large, it means that the population will double in under 35 years-that is, according to current projections (which our ecologist friends warn us should not be confused with predictions) (e.g. Meadows et al., 1972). This growth is not merely the result of a rising birth-rate, aided by a drop in infant mortality rates; medical knowledge and public health programmes have reduced the death-rate as well. By the end of this century over $80 \%$ will live in the developing world (Cabinet Office, 1976). Even if fertility rates were to be reduced to the replacement level now, the existing age structure of the world's population would ensure continued growth for another two generations.

Attitudes to population growth vary from place to place. I have farms in Brazil and Jamaica, so speak with first-hand experience of these places. Each presents a different aspect of the population problem.

Brazil is a vast country with a relatively small population which is growing at the rate of $2.8 \%$ a year, and at this rate should double in 25 years. Latterly about $42 \%$ of the people were under fifteen years old, so a much larger growth of population seems inevitable in the near future unless there is widespread birthcontrol. Fifty-nine per cent of Brazil's population lives in urban areas, such as the cities of Rio de Janeiro and São Paulo, and in the north-east region, where there are also critical social and urban problemsparticularly slums caused by over-population. While the Government does not oppose the right of its people to plan the size of their families, it regards the issue as politically sensitive, and does not sponsor birth-control programmes-for two main reasons. First, the Roman Catholic Church opposes birthcontrol. The 1968 Papal Encyclical Humanae vitae teaches that it is sinful. This stand has greatly reduced the Church's ability to take a leading role in solving the population problem (Murphy \& Erhart, 1975). Secondly, some Brazilian nationalists want a bigger population, to build up the country's economy and to occupy empty areas for security reasons (Onis, 1977).

Jamaica is a small island with a large population. In the past emigration, primarily to Britain, offset the effects of its population growth; but then Britain, for very good reasons, closed the door, and this has forced the problem back onto Jamaica. Jamaica's population problem is great. With a growth-rate of $2.3 \%$, the population is projected to double in 30 years; $46 \%$ of it is under 15 years of age, thus promising further growth in the near future. In 1968 the Jamaican Government announced its intention to reduce the birth-rate from 34.2 per thousand to 25 per thousand by 1976 (Schroeder \& Taeuber, 1974). This target was not reached.

\section{Solutions to the Population Problem}

How can the world population problem be solved? Birth control is one answer. There are many reasons why the poor have children; security in their old age, additional help on the land, cultural preference for sons, laws of inheritance, traditional religious behaviour, and personal pride. Individuals must realize the need to limit the size of their families, but this can only come about when they have reasons to do so. The factors which seem to lead to a decline in fertility include reductions in infant and child mortality rates, expansion of basic education with an increase in the proportion of girls in school, an increase in the productivity of smallholders in rural areas, stress on more equitable distribution of incomes and services, and a rise in the status of women (McNamara, 1977). It takes time to improve standards of living and to educate people so that they will want fewer children. But do we have the time? Every increase in population makes it that much more difficult to improve standards of living.

There is a difference between birth control-voluntary planning and action by individuals - and population control, or action on the belief that, for the good of society in the light of over-population, individuals and groups should reduce the number of children they 
produce. Singapore has tried a measure of the latter. Couples are penalized for having more than two children: charges in maternity hospitals increase sharply after two births, income-tax deductions decrease after a third birth, and couples who volunteer for sterilization after having two children are given priority in selecting their children's educational institutions (Hazelhurst, 1976). In China, birth control material is free, there are family planning clinics in every commune and factory, extra-marital sex is regarded as a gross social transgression, and people are encouraged to marry late and to have only two children (Bonavia, 1974). The Chinese Government claims that this programme has significantly reduced the country's birth-rate.

\section{Migration}

Today, the mass migration from the hinterlands to the cities is a problem which every developing country faces (Ward, 1976). For example, of Jamaica's 2.1 million people, $37 \%$ live in the capital city of Kingston. People move to the cities, as the London Times noted (Anon., 1976):

'from an agricultural system that cannot support them, which has the dual effect of making the rural areas even less able to supply food to the cities and swamping the cities with people for whom there are no jobs. The result is a great deal of poverty and the destruction of almost any rational pattern of economic development.'

This influx of people accentuates all urban problems: housing, unemployment or underemployment, overcrowding, poor transportation, inflation, lack of educational and vocational opportunities, lack of sanitation, water, low-priced fuel, and food. Pollution in all forms is increasing. In an unfamiliar environment, old values break down. The frustration of slum dwellers can lead, as in New York City latterly, to increases in crime and violence, threatening concepts of personal security and rights (e.g. Brown et al., 1976). These urban problems will partly disappear with economic growth; yet it is difficult for a developing country to become an industrial nation in a hurry. The human costs and social consequences of slow growth may be very great.

\section{FOOD SUPPLIES}

The second challenge faced by the developing world is to provide food for its growing population. In 1976 the Worldwatch Institute, of Washington, D.C. (Brown et al., 1976), gave an excellent example of the interaction between population and food supply:

'A comparison of North America and Latin America, two regions roughly equal in size and resources, illustrates the devastating role of rapid population growth. As recently as 1950, both North America and Latin
America had essentially the same population size, 163 and 168 millions, respectively. But the difference since then explains why North America emerged as the world's breadbasket while Latin America became a net food importer. While North America's population growth has slowed substantially since the late fifties, that of many Latin American countries has expanded at an explosive 3 per cent or more yearly. If North America's 1950 population had expanded at 3 per cent per year, it would now be 341 millions rather than the actual 236 millions. Those additional 105 million people would absorb virtually all the current exportable surpluses, and North America would be struggling to maintain selfsufficiency.'

Given that population is growing very widely and that the amount of land suitable for agricultutal purposes is limited, how will people be fed? There will come a time, not very far distant, when all agricultural land will be fully utilized, by the most modern methods, and so will be producing to capacity. If the world's population continues to grow, there could be very serious consequences.

New sources of food will be found, and there will no doubt be further 'green revolutions'-i.e. increasing the yield on land that is already under cultivation by improved varieties of wheat, maize, and rice. But there are problems inherent in the green revolution: it tends to produce monocultures about which many authors have now warned us. The new grains give their increased yields only when they are used in conjunction with much higher amounts of expensive fertilizer than were formerly employed. We in the developed world know the dangers of pollution problems emanating from the over-use of fertilizers and pesticides. In addition, new strains require more water than traditional varieties, thus demanding capital investment for irrigation that is often beyond the reach of poor farmers, and putting pressure on limited sources of water.

As an example, India doubled her food production between 1965 and 1971. This was accomplished by increasing yields and crop areas. But further increases in cropland are dependent upon irrigation as well as upon improving the country's infrastructure-such as market facilities, storage areas, and transport. Development of the infrastructure has not kept pace with the harvests, because the large investments necessary have not been available (Mauksch, 1976).

Food supply is always dependent upon the weather. The 1975 frost, which ruined the Brazilian coffee crop, is an example of how vulnerable agriculture is to the climate. In terms of people, hundreds of millions will continue to live at starvation level or near to it, with the consequent malnutrition which saps energy and initiative. Our challenge, then, is to increase the world's food supply, by making better use of land under cultivation and by helping to build up the necessary infrastructure. 


\section{Personal Experiences}

My own experience in Jamaica provides an example of some other aspects of the problem of agriculture in the developing world. My farm there, on the northern coast of the island where the land is difficult to cultivate, was under-developed when I bought it in the 1930s. My most pressing problem was lack of water. There was plenty in the near-by White River, which never goes dry, but the problem was to raise it from a deep gorge. The cheapest method to get water was to erect a hydroelectric plant. The plans, drawn up in 1937, provided for a power supply that would be greater than anything I needed; so I applied for rights to supply power to the two adjacent towns of Ocho Rios and Oracabessa, neither of which had any electricity. My electricity supply started during the Second World War and resulted in a considerable saving of oil. After the War, the Jamaica Public Service Company bought the plant from us.

The estate is largely devoted to the cultivation of citrus fruits, principally limes, with some pastureland and coconuts. Another crop is allspice. When I first owned the property the labourers at harvest time used to break off the branches to get the fruit. My foreman explained this seemingly destructive method to me: Jamaicans believed that the use of steel to cut the clusters would kill the trees. That prejudice we have with difficulty overcome.

\section{EDUCATION}

Human beings are our greatest natural resource, and the third challenge which the developing world faces is to educate them. We like to think that we have largely won the battle in the developed world, but an Adult Performance Study conducted by the University of Texas in 1974 concluded that, in the United States, as many as $20 \%$ of adults were for all practical purposes illiterate, and an additional $33 \%$ were only 'marginally competent' (World Education, 1975). The problems of the developing world are huge, and several 'vicious circles' exist, one being that 'High rates of population growth reduce educational opportunities for women in developing countries, and undereducated women have high fertility rates and perpetuate a situation where population growth outruns educational budgets and manpower' (Ibid.). A modern industrial base depends upon skilled labour, which comes if a society has the resources to provide education; this is achieved more easily if there is an industrial base.

I have long recognized the need for more education in the developing world, and in 1956 started Prospect College in Jamaica. My object was to train boys for citizenship. Jamaica is a developing country: it needs trained young people. The College is in no way a local school; boys are accepted from all over the island.
Our course is for three years. We take much trouble to train our boys, both in academic work and in an intelligent and self-reliant approach to life. All get a measure of training on the land, so they have some skills whatever they may come to do later in life.

New skills must be used to improve-and perhaps even to perpetuate-life on Earth. Can we ask skilled men to go back to the land, to do back-breaking work that they could do better with machines which they know how to use and repair? The Chinese and Cambodians have done just this, but is it possible for a democracy to do so? Increasing mechanization does cause unemployment by reducing the number of workers needed on the land. Would I be contributing more to Jamaica, in the long run, if I limited the amount of mechanization on my farm and used more men? I would be reducing the employment problem by a small amount, but I would also be eliminating jobs for skilled men. These are the sort of questions that arise all over the world.

\section{CONCLUSION}

We have inherited a world with many advantagesand many problems. I think the real basis for hope in the future is Man himself, with his ability to foresee the problems ahead and to alter his behaviour, while avoiding difficulties and developing solutions to his problems (UNESCO, 1977). We must try to present future generations with a world of balance and stability which offers adequate facilities and contentment to all. This is perhaps an impossible task, but it should be our long-term aim. To solve our problems, a measure of political and of economic balance is vital. While I am not suggesting a world state, the need for cooperation is very great. We can only solve our problems and meet our challenges by a joint effort-by sharing our knowledge and resources.

Clearly our immediate efforts should be directed towards eliminating the great variations in standards of living between different countries, and in helping every country at least to feed and clothe its people. This will be an enormous task and will demand sacrifices from us. Pessimists have predicted the death of much of what we know and love, and have even written the obituaries. Our task is to find ways of giving our world new life and hope, and of extending its advantages to all people.

\section{SUMMARY}

Six problems faced by the developed and developing worlds are discussed and possible solutions are considered. Given its relatively stable populations and adequate food supplies, the developed world must be prepared both to pay for and to encourage efforts to control pollution of the environment. Its comparative over-consumption of energy must be coun- 
tered by the development of new energy sources, bearing in mind the risks involved in the use of nuclear energy. Also, great efforts must be made to assist the developing world by improving the quality and quantity of aid and by voluntary changes in world trade patterns.

The developing world's most serious problem is its exploding population which can be slowed by birth control and improved standards of living. Population growth puts pressure on cities, and makes it imperative that new sources of food be found and new agricultural techniques be developed. Population also exacerbates the difficulties of providing education in the developing world.

Hope for the future rests on Man's capacity to foresee problems and to solve them.

\section{References}

Anon. (1976). Devouring Cities. The Times (London), 31 May. ANON. (1977a). Wheat to eat. The Economist, 10-16 September, pp. $85-6$.

AnON. (1977b). Time (European Edition), 2 May, p. 6.

ANON. (1977c). Recutting the world economic pie. International Herald Tribune, 4-5 June.

ANON. (1977d). The rich should buy more from the poor. The Times (London), 18 June.

AnON. (1977e). Mr Carter's world view. The Times (London), 1 June.

Bonavia, D. (1974). China: Pressure on food and resources denied. The Times (London), 19 August.

Bouvier, L. F. (1975). U.S. population in 2000-zero growth or not? Population Bulletin, 30(5), $32 \mathrm{pp}$.

Brown, L. R., McGrath, P. L. \& Stokes, B. (1976). Worldwatch Paper 5: Twenty-Two Dimensions of the Population Problem. Worldwatch Institute, Washington, D.C.: 83 pp.

CABINET Office (1976). Future World Trends. Her Majesty's Stationery Office, London, England: $26 \mathrm{pp}$.

Edsall, J. T. (1974). Hazards of nuclear fission power and the choice of alternatives. Environmental Conservation, 1(1), pp. 21-30.

EdSALL, J. T. (1975). Further comments on hazards of nuclear power and the choice of alternatives. Environmental Conservation, 2(3), pp. 205-12.

Ehrlich, P. (1971). The Population Bomb. Ballantine Books, New York, N.Y.: xiv +201 pp.

Fanon, F. (1963). The Wretched of the Earth. Grove Press, New York, N.Y.: 316 pp.

\section{Suggestion of an Award for the Best Contribution Each Year to Environmental Conservation}

Fortified by comments from reviewers and others, we have come to feel that so many outstanding papers are being submitted to us that it might well be appropriate to establish a yearly prize for the best one published in each volume of Environmental Conservation-naturally hoping it would be the best paper on an environmental topic published anywhere!

Suggestions as to the most desirable form and administration of such an award would be welcomed by the undersigned, and would be considered in preparing a draft constitution to govern it under the general aegis of our sponsoring Foundation for Environmental Conservation.

One idea which has come to us already is that a not-too-
FIELD, M. (1977). North-South nations find that goodwill is not enough. Daily Telegraph (London), 3 June.

HARE, F. K. (1977). Is survival worth while? Environmental Conservation, 4(1), p. 2.

Hazelhurst, P. (1976). Singapore becomes model for Asia. The Times (London), 28 August.

MaUkSCH, M. (1976). India's Population. International Herald Tribune, 9 April.

MCNamara, R. S. (1977). An Address on the Population Problem. International Bank for Reconstruction and Development, Washington, D.C.: 57 pp.

Meadows, D. H., Meadows, D. L., Randers, J. \& Behrens, W. W. (1972). The Limits to Growth. Earth Island Limited, London, England: $205 \mathrm{pp}$.

Moore, R. (1975). Man in the Environment. Alfred A. Knopf, New York, N.Y.: viii +155 pp.

Murphy, F. X. \& ERharT, J. F. (1975). Catholic perspectives on population issues. Population Bulletin, 30(6), $31 \mathrm{pp}$.

ONIs, J. De (1977). Efforts to take politics out of family planning. The Times (London), 9 May.

Polunin, N. (Ed.) 1972). The Environmental Future: Proceedings of the first International Conference on Environmental Future, held in Finland from 27 June to 3 July 1971. Macmillan, London \& Basingstoke, and Barnes \& Noble, New York: xiv +660 pp., illustr.

Polunin, N. (Founder \& Ed.) (1974-). Environmental Conservation: the Scientific Journal Devoted to Global Survival. Elsevier Sequoia, P.O. Box 851, 1001 Lausanne 1, Switzerland: $80 \mathrm{pp}$., illustr., quarterly.

Population Reference Bureau (1977a). 1977 World Population Data Sheet. Population Reference Bureau, Washington, D.C.: $1 \mathrm{p}$.

Population Reference Bureau (1977b). Energy: Increasing consumption, decreasing resources. Interchange, 6(1), $4 \mathrm{pp}$.

Schroeder, R. C. \& Taeuber, C. (1974). Policies on population around the world. Population Bulletin, 29(6), $35 \mathrm{pp}$.

Schumacher, E. F. (1973). Small is Beautiful. Harper \& Row (Perennial Library), New York, N.Y.: viii +305 pp.

Tinbergen, J. (Coordinator) (1977). Reshaping the International Order. Hutchinson, London, England: $325 \mathrm{pp}$.

UNESCO (1977). Round Table on the Challenge of the Year 2000. UNESCO, Paris, 28-30 June [not available for checking].

WARD, B. (1976). The Home of Man. Penguin Books, London, England: xii $+294 \mathrm{pp}$.

Ward, B. \& Dubos, R. (1972). Only One Earth. Penguin Books, London, England: $304 \mathrm{pp}$.

WillRich, M. (1976). Energy independence for America. International Affairs, 52(1), pp. 53-66.

Willrich, M. \& TAYlor, T. E. (1974). Nuclear Theft: Risks and Safeguards. Ballinger Publishing Company, Cambridge, Massachusetts: xvi $+243 \mathrm{pp}$.

WORLD EduCatron (1975). Literacy and world population. Population Bulletin, 30(2), 29 pp.

modest prize of money, named after (or at the instance of) a worthy corporate or personal donor, would be most welcome in encouraging and rewarding good work and writing. If such a donor of the capital amount needed for endowment should come forward this year, we could set up forthwith a small and independant ad hoc jury to which nominations or personal submissions should be sent. The first award could then be for the best paper published in 1978 according to the jury's final decision.

\section{Nicholas Polunin}

15 Chemin F.-Lehmann, 1218 Grand-Saconnex, Geneva, Switzerland. 